\title{
Hematological Analysis of Oreochromis niloticus and Clarias sp. Cultivated in Integrated Fish Farming
}

\author{
Dian Fita Lestari ${ }^{1{ }^{*}}$ Fatimatuzzahra $^{1}$ \\ ${ }^{1}$ Biology Department, Faculty of Mathematics and Natural Sciences, University of Bengkulu \\ *Corresponding author. Email: dianfita@unib.ac.id
}

\begin{abstract}
The demand for cultivated fish for public consumption has increased. One of the fish farming methods was a fish pond that is integrated with poultry, especially the types of fish that are easy to cultivate such as tilapia (Oreochromis niloticus) and catfish (Clarias sp.). The aim of this research was to determine the hematological analysis of tilapia and catfish cultivated in the integrated fish farming. The result of the study, physicochemical water parameter showed that the pond has a low $\mathrm{pH} \pm 3,4$ and dissolved oxygen $\pm 2,6 \mathrm{ppm}$. The tilapia fish had erythrocyte levels of $20,34 \times 10^{5}$ cells $/ \mathrm{mm}^{3}$ and leukocyte levels of $189,6 \times 10^{3}$ cells $/ \mathrm{mm}^{3}$ while the catfish had erythrocyte levels of $29,62 \times 10^{5}$ cells $/ \mathrm{mm}^{3}$ and leukocyte levels of $113,7 \times 10^{3}$ cells $/ \mathrm{mm}^{3}$. Leukocyte and erythrocyte levels in both fish have a different response. The water environment with the integrated fish farming system is shown to have a low $\mathrm{pH}$ because of chicken manure and feed residue that entered the fish pond, which is causing the nitrification process and causing the dissolved oxygen to be very low.
\end{abstract}

Keywords: blood, integrated fish farming, physicochemical

\section{INTRODUCTION}

The government program, which campaigns to encourage people to consume fish, is an opportunity to promote the potential of fish breeders. One of them is freshwater fish cultivation. Various methods have been developed to produce fish in large quantities, but they are efficient in terms of time and budget. In fact, it does not rule out the possibility for other breeders such as poultry farmers to produce fish and poultry simultaneously. This method is known as poultry integrated fish farming or Long-yam in several areas in Indonesia (balong-ayam or chicken coops). This cultivation system of chickens will be raised above the pond so that the scattered feces and feed that are not consumed by the chickens will enter the pond [1]. The manure that enters will become organic fertilizer for the pond, and the remaining feed can be eaten by fish, thus saving more production costs.

Several types of fish chosen by the breeders to be cultivated are tilapia (Oreochromis niloticus) and catfish (Clarias sp.), which are commercial fish that are popular with the general public. Besides, based on several studies, tilapia and catfish can adapt to various environmental conditions. As stated by [2] and [3] tilapia and catfish are popular fish that are quite popular with the community and have a wide tolerance limit so that tilapia and catfish have the potential to be cultivated from freshwater to local areas, beaches with brackish waters.

Integrated fish farming with poultry farming is currently widely practiced by the community because it is considered more efficient in space, saves fish feed, and has more benefits because it can harvest chicken and fish. The poultry is placed on the top and the fish pond on the bottom, so that the chicken feces enter the fish pond which can be used as fish feed, thereby reducing the amount of fish feed. However, environmental factors in fish cultivation ponds are, of course, very influential on fish physiology. But there is not much information related to the physiological conditions of fish living in integrated ponds with poultry. The hematological index is related to pathological conditions, to obtain the health condition of the fish [4]. Therefore, physiological observations are made by observing the hematological analysis of tilapia and catfish cultivated in integrated fish farming. 


\section{MATERIALS AND METHODS}

The research was conducted at one of the integrated fish farming with chicken coops (poultry) in North Bengkulu. Samplings were taken in November-December 2019. A total of 18 fish samples were taken randomly from the ponds for tilapia and catfish.

\subsection{Water Parameters}

The parameters of physicochemical water samples were randomly taken from an upstream, pond, and downstream within the early hours of the morning $(08.00-09.00 \mathrm{~h})$. Temperature and $\mathrm{pH}$ were determined using the Hanna Instrument handheld meter after calibrations. Conductivity was determined using a conductivity meter. The concentration of the dissolved oxygen was determined using the modified Winkler Azide method as described by Lind (1979) and APHA (1985). Dissolved oxygen was analyzed by the Winkler titration method which is generally used to determine dissolved oxygen levels. The principle is by using iodometric titration. The sample to be analyzed, first added with a solution of $\mathrm{MnCl}_{2}$ and $\mathrm{NaOH}-\mathrm{KI}$, so that $\mathrm{MnO}_{2}$ deposits will occur. By adding $\mathrm{H}_{2} \mathrm{SO}_{4}$ or $\mathrm{HCl}$, the sediment that occurs will dissolve again and release the iodine $\left(\mathrm{I}_{2}\right)$ molecule, which is equivalent to dissolved oxygen. The liberated iodine was titrated with a standard solution of sodium thiosulfate $\left(\mathrm{Na}_{2} \mathrm{~S}_{2} \mathrm{O}_{3}\right)$ and used as an indicator of starch solution.

\subsection{Blood Sampling}

The fish that will be taken blood is first anesthetized until the fish is unconscious. The fish blood that has been taken from the caudal artery with a syringe and given 10\% EDTA is ready to be observed for its hematological parameters. The calculation of red blood cells or erythrocytes was carried out based on the Klontz method, the blood sample is taken from an Eppendorf tube using an erythrocytes suction device in the form of a capillary with a small red stone inside until the line shows 0.5 $\mathrm{ml}$. Add the hayem solution until the solution reaches $101 \mathrm{ml}$ and homogenize it by shaking it. Two drops of blood are discarded to remove air bubbles, then dropped into the counting room which is closed with a glass cover. Furthermore, it was observed under a microscope with a magnification of $10 \times 10$ with 5 fields of view in a small box in the hemacytometer count room, and the calculation was carried out with the formula:

The number of erythrocytes $=\mathrm{n} \times 10^{4}$ cells $/ \mathrm{mm}^{3}$
The counting of white blood cells or leukocytes was taken from the Eppendorf tube using a leukocytes suction device in the form of a capillary with small stones in it that was white until the line showed $0.5 \mathrm{ml}$. Furthermore, the Turk solution is added until the solution reaches $11 \mathrm{ml}$ and homogenizes it by shaking it well. Two drops of blood are removed to remove air bubbles. Blood is dripped into the hemacytometer count room and covered with a glass cover. The blood was observed under a microscope with a magnification of $10 \times 40$ with 4 fields of view in a large box in the hemacytometer count room, and the calculation was carried out with the formula:

The number of leukocytes $=\mathrm{n} \times 50$ cells $/ \mathrm{mm}^{3}$

\section{RESULT AND DISCUSSION}

The tilapia fish (Oreochromis niloticus) has become a popular fish species worldwide because tilapia is a valuable fish. Besides, being easy to breed, tilapia can grow in a variety of aquaculture systems [5]. Catfish (Clarias sp.) is one of several types of freshwater fish that has been cultivated commercially by the people of Indonesia [6]. According to the Human Resources Development Agency, of the Ministry of Marine Affairs and Fisheries, catfish is a leading commodity because it is easy to cultivate, can be maintained with high stocking density in limited land in marginal areas, and it saves water. The growth of fish is responsive to various environmental factors, such as physicochemical factors and fishing [7]. Water quality is the main parameter in the success of fish farming. The physical and chemical characteristics of this water are very basic and very influential on fish. Environmental factors that can generally affect fish lives include acidity $(\mathrm{pH})$, dissolved oxygen (DO), conductivity, and temperature. Fish cultivators must always control and maintain water quality for the success of fish farming [8]. The influence of water quality on cultivation activities is very important so that the controlling of water quality parameters is necessary for cultivators [9]. The aquatic environment affects the maintenance, growth, and reproduction of cultivated fish. If water quality exceeds tolerance limits, it will cause disease in fish. Fish ponds with good water quality can support the life of fish and other organisms in them.

Conductivity is a parameter to determine electrical conductivity. Electrical conductivity measurement to measure the ability of the ions in water to conduct electricity and predict the mineral content in water. Measurements based on the ability of cations and anions to deliver the electric current that is flowing in the water sample can be used as an 
indicator, where the greater the value of the electrical conductivity, the greater the ability of cations and anions. The conductivity of the water depends on the number of dissolved ions per volume and the mobility of these ions. Conductivity increases by the same amount as salinity increases. In general, the more dominant factor in changing the conductivity of water is temperature. This indicates that more minerals are contained in water. This electrical conductivity is measured at standard temperatures, namely at $25^{\circ} \mathrm{C}$. The usual conductivity in freshwater aquaculture is $0-5000 \mu \mathrm{S} / \mathrm{cm}$. Based on the measurement results (Figure 1a) shows that the range of conductivity in the upstream (part of the water storage pool before the integrated fish pond chicken coop) is $57 \mu \mathrm{S} / \mathrm{cm}$ and in the fish raising pond directly under the chicken coop is $76 \mu \mathrm{S} / \mathrm{cm}$. In the downstream, there is a decrease in conductivity (the bottom pond after the fish pond) where the remaining water from the fish pond is flown for disposal. This shows that the presence of chicken feces causes conductivity to increase. This clearly shows that the presence of minerals from chicken, fish, and feed waste will affect the dissolved particles, thereby increasing the conductivity of the fish pond.

\section{CONDUCTIVITY}

E Conductivity

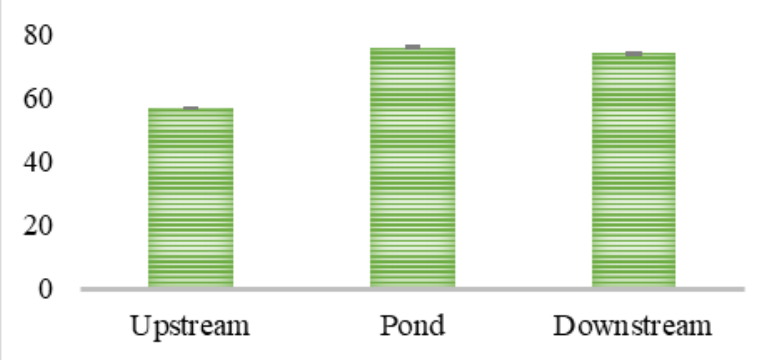

(a)

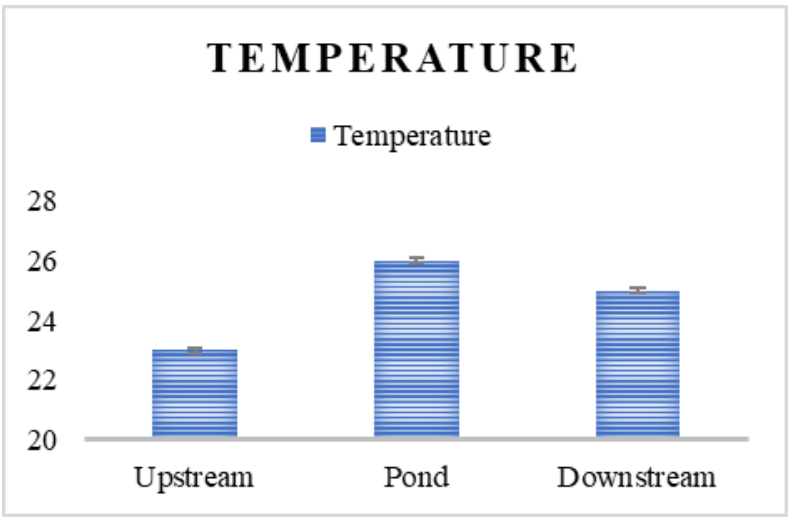

(c)

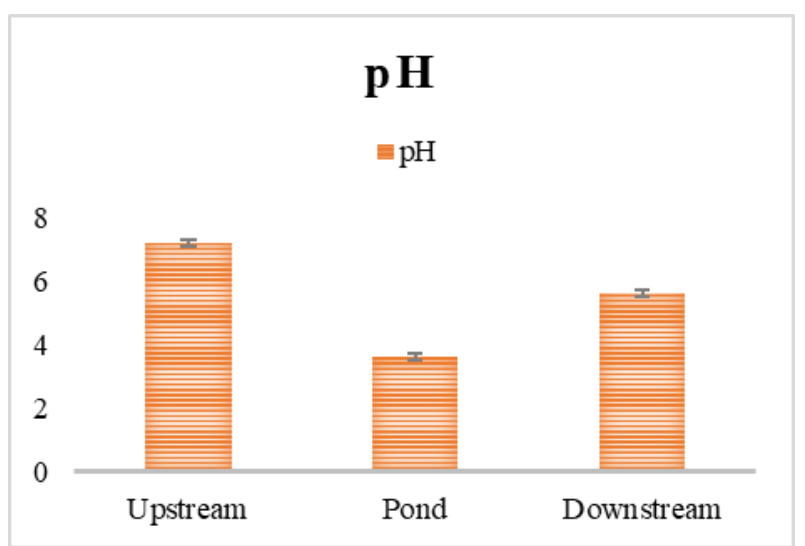

(b)

\section{DISSOLVED OXYGEN}

$\equiv$ Dissolve Oxygen

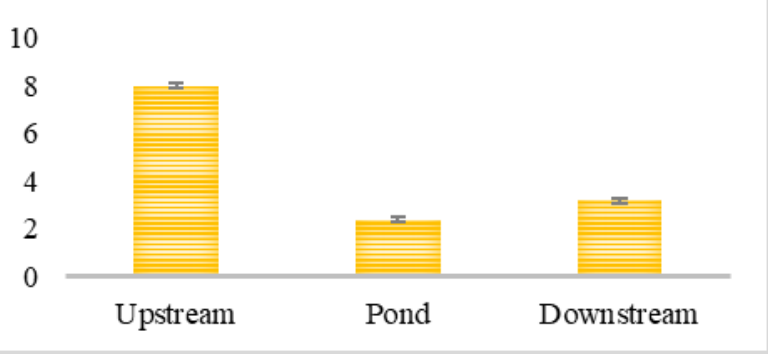

(d)

Figure 1. Physicochemical water test. (a). conductivity; (b). pH; (c). temperature; (d). dissolved oxygen

The degree of acidity of water is generally due to water-soluble oxide gases, especially carbon dioxide. A $\mathrm{pH}$ that is too low or too high can cause several chemical compounds to turn into toxins which are very harmful to the health of fish. If the $\mathrm{pH}$ is monitored and controlled at a pH value of 6 to 9 , then the growth of catfish shows more optimal results. Water quality for catfish based on SNI (Indonesian National Standard) Number 01-6484.5-2002, which is suitable for catfish with a $\mathrm{pH}$ value of 6.5-8.5. Based on (Figure 1b), shows that the $\mathrm{pH}$ is very different in the upstream part which has a normal $\mathrm{pH}$ of 7.2. The water sources in the upstream part come directly from mountain springs that flow through rivers and are collected for flow in fish ponds. Meanwhile, the fish pond (under the chicken coop) has an acidic $\mathrm{pH}$ of 3.6. This indicates that the presence of chicken manure and chicken feed residue will enter the pond, which makes the $\mathrm{pH}$ of the pond water acidic. A pH of less than 5 is very bad for fish because it can cause clumping of mucus in the gills, while a $\mathrm{pH}$ of 8 and above causes a reduced appetite 
for catfish [6]. A $\mathrm{pH}$ is one of the environmental factors that affect the growth and activity of ammonia-oxidizing bacteria.

Nitrification bacteria prefer an alkaline environment with an optimal $\mathrm{pH}$ level for heterotrophic bacterial growth, ranging from 7.5-8.5. Ammonia comes from feces and chicken feed, but also from uneaten fish feed, feces, and metabolic products that enter the waters. Ammonia is a toxic compound and a growth-inhibiting factor, at a concentration of $0.18 \mathrm{mg} / \mathrm{L}$ it can inhibit fish growth. The increase in leftover feed and accumulation of metabolic waste can cause water quality to become low because of the increasing phosphate concentration and can decrease dissolved oxygen levels in the waters. High phosphate concentrations will interfere with metabolic processes and can even lead to fish mortality [10]. Metabolic waste and feed residue that settles at the bottom of the pond can cause the waters to become cloudy. The cloudiness of pond waters can reduce sunlight entering the waters and can inhibit phytoplankton from photosynthesis. If this happens, it can reduce water productivity and decrease water quality.

The growth of catfish based on SNI Number 016484.5-2002 will be good if maintained in water temperatures and warm environments between $25^{\circ} \mathrm{C}-$ $30^{\circ} \mathrm{C}$, and from the research [11], the optimal for tilapia growth is $22-30^{\circ} \mathrm{C}$. Changes in water temperature in rearing ponds are kept at less than $4^{\circ} \mathrm{C}$. Changes in temperature that are too extreme will cause stress for fish and can cause fish mortality. The temperature based on the measurement results (Figure 1c) shows that the water in the upstream part is $23^{\circ} \mathrm{C}$ because it comes from mountain water, but in the pool the temperature is $26^{\circ} \mathrm{C}$, this is because of the hot chicken droppings that can cause the water temperature to increase. In the downstream part, the water temperature decreases because it is not directly exposed to chicken manure. Above $30^{\circ} \mathrm{C}$, the appetite for African catfish will decrease. In addition, the high water temperature will increase the metabolic activity of the existing organisms.

In water quality, oxygen has an important role as an indicator because dissolved oxygen concentration plays a role in the oxidation and reduction processes of organic and inorganic materials. Oxidation and reduction processes that make dissolved oxygen are very important to reduce the load of natural water pollution [4]. Dissolved oxygen (DO) is a limiting factor in the culture system. If DO is not maintained at an adequate value, then the fish will become stressed and cannot eat well [12]. Water quality for catfish SNI Number 01-6484.5-2002 with dissolved oxygen more than $4 \mathrm{mg} / \mathrm{L}$. The dissolved oxygen content in water is suitable for the life and growth of tilapia more than $3 \mathrm{ppm}$, lower than catfish. Based on (Figure 1d) shows that DO in the upstream part is 8 $\mathrm{mg} / \mathrm{L}$, meaning that the dissolved oxygen content in the water before entering the pond is quite high, but DO in the fish pond is only around $2.4 \mathrm{mg} / \mathrm{L}$. This shows that in fish ponds, the amount of oxygen is greatly reduced, this is of course a big threat to fish life. In the fish pond, there is no aerator or equipment for oxygen supply, the pond is only allowed to receive continuous flow from the upstream. Whereas oxygen is very necessary for the respiration and metabolism of fish and microorganisms in water. The oxygen content that is not sufficient for the needs of fish and other biota can cause a decrease in fish survival. Some fish also often die at the beginning of growth. According to [13], fish that have additional breathing tools such as catfish grow faster on oxygen more than $3 \mathrm{ppm}$. If in low oxygen conditions, fish always appear on the surface to breathe oxygen which drains energy, so the growth process is inhibited.

The condition of the aquatic environment in the tilapia and catfish aquaculture ponds will certainly greatly affect the physiological condition of the fish body, one of which is blood which functions in body defense, oxygen, and nutrient transportation. The number of erythrocyte levels (Figure 2) in tilapia is equal to $20.34 \times 10^{5}$ cells $/ \mathrm{mm}^{3}$, but blood counts of the catfish had erythrocyte levels of $29.62 \times 10^{5}$ cells $/ \mathrm{mm}^{3}$. According to [14], the number of normal erythrocytes in tilapia ranges from 20.000-3.000.000 cells $/ \mathrm{mm}^{3}$. The number of erythrocytes which are low but still normal. Factors that affect the value of fish erythrocytes include age, sex, environment, nutrition, and oxygen deficiency conditions. The number of erythrocytes is influenced by water temperature. The high temperature will cause a decrease in the number of erythrocytes. Many factors can cause the reduction of the erythrocytes. The number of erythrocytes is also influenced by disease and appetite. Fish that are affected by disease or have decreased appetite, then the blood hematocrit value becomes abnormal and followed by a low number of erythrocytes, and also caused by the polluted aquatic environment [15].

In catfish, this total erythrocyte number is higher than in tilapia, but still suitable for healthy catfish erythrocytes. The results of this study are normal range, ranging from 1.000.000-3.000.000 cells $/ \mathrm{mm}^{3}$. High erythrocyte levels indicate that the fish are in a state of distress. In addition, the low of erythrocytes can cause fish to be unable to take in amounts of oxygen even though the availability of oxygen in the waters is sufficient. As an effect, the fish will encounter anoxia.

Blood counts of leukocyte levels (Figure 3) in tilapia of $189.6 \times 10^{3}$ cells $/ \mathrm{mm}^{3}$ and catfish had a 
leukocyte level of $113.7 \times 10^{3}$ cells $/ \mathrm{mm}^{3}$. According to [14], the normal leukocyte count in tilapia ranges from 20.000-150.000 cells $/ \mathrm{mm}^{3}$. The number of leukocytes was increasing, more than the normal number. The number of leukocytes in fish is influenced by several factors, the type of species, age, and muscle activity. Increasing the concentration of leukocytes positively impact on the formation of antibodies, thus indicating the body's resistance response to foreign substances. The immunostimulant contained in earthworms can increase the immunity of fish, especially increasing white blood cells which have an important role in the formation of antibodies and disease prevention. Leukocytes will increase when fish are infected as a form of the body's immune response against microorganisms. The chicken manure that enters the fish pond, can make the number of microorganisms that make tilapia defense and the presence of many microorganisms in water may cause the low oxygen content. It can also indicate environmental stress. Based on observations, it shows that tilapia has a relatively smaller body size than if it is cultivated in clean water. In tilapia culture, in addition to the presence of oxygen, $\mathrm{NH}_{3}$ is a growth-inhibiting factor, at a concentration level of $0.18 \mathrm{mg} / \mathrm{L}$ it can inhibit fish growth [16].

The number of leukocytes in catfish obtained was still in the normal range of catfish $20-150 \times 10^{3}$ cells $/ \mathrm{mm}^{3}$ [17]. According to [18], leukocytes will decrease if the fish response to stress, such as heat stress. [19] stated that changes in aquatic environmental conditions, changes in water quality, and the lack of natural food can cause a decrease in the number of leukocytes in fish, causing a decrease in antibody production, decreased body resistance, and susceptibility to disease. Based on the observation, catfish that cultivated in the integrated system has a larger size, this can be due to catfish can be adapt to unfavorable water environment than tilapia.

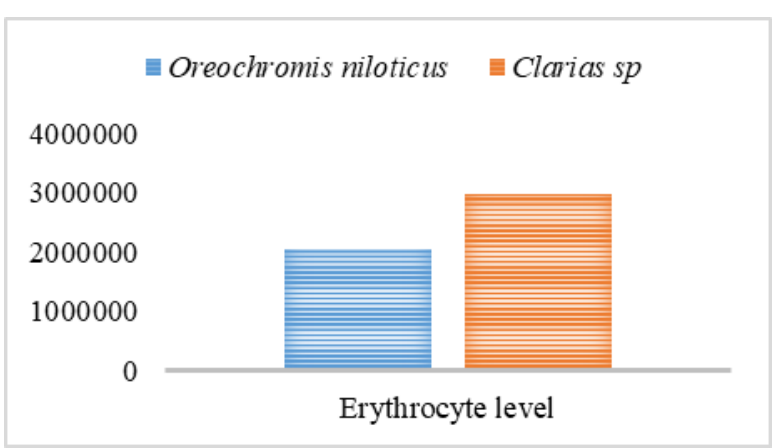

Figure 2. Blood levels of erythrocyte in tilapia (Oreochromis niloticus) and catfish (Clarias $\mathrm{sp}$ )

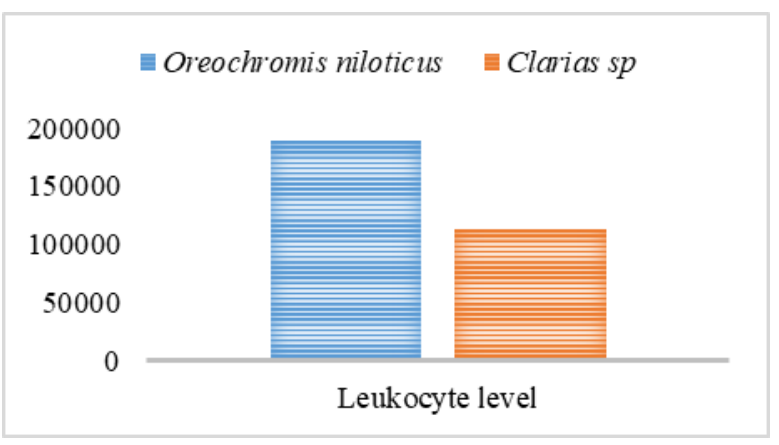

Figure 3. Blood levels of leukocyte in tilapia (Oreochromis niloticus) and catfish (Clarias sp)

The optimum total value of white blood cells in fish determines the health status of these fish. The number of leukocytes that deviate from normal conditions has important clinical significance for the evaluation of disease processes. Increasing the number of leukocytes can be used as an indication of the first phase of infection, stress, and leukemia. If the fish is infected, the leukocyte cells will be transported specifically to the infected area.

\section{CONCLUSION}

The tilapia fish (Oreochromis niloticus) had erythrocyte levels in the normal range but had a more than normal range of leukocyte levels. The catfish (Clarias sp) had erythrocyte levels in the normal range and a level of leukocyte levels in the normal range. Both tilapia and catfish have different numbers of leukocytes and erythrocytes even though they are maintained in the same environment. Environmental stressor factors can be caused by the manure of the chicken coop that has a different effect on each fish species.

\section{REFFERENCES}

[1] The Food and Fisheries Security Service of Buleleng $\quad 2020$. https://dkpp.bulelengkab.go.id/.

[2] A.S. Fitria, Analisis kelulushidupan dan pertumbuhan benih ikan nila (Oreochromis niloticus) F5 D30-D70 pada Berbagai Salinitas, Journal of aquaculture management and technology, 1 (1) (2012) 18-34. [In Bahasa Indonesia]

[3] M.H.F.Sitio, D. Jubaedah, M. Syaifudin, Survival and growth of juvenile catfish (Clarias sp.) at different media salinity, jurnal 
akuakultur rawa indonesia, 5 (2017) 83-96. DOI: https://doi.org/10.36706/jari.v5i1.5810.

[4] N. A. Zuhrawati, The Influence of rising temperatures towards the levels of hemoglobin and hematokrit value tilapia fish (Oreochromis niloticus), Journal of medical veterinaria, 8 (1) (2014) 84-86.

[5] M.M.N. Authman, H.H. Abbas, W.T. Abbas, Assessment of metal status in drainage canal water and their bioaccumulation in Oreochromis niloticus fish in relation to human health, Environmental monitoring and assessment, 185 (2013) 891-907. DOI: 10.1007/s10661-012-2599-8.

[6] R. Alnanda, Djayus, R. Ezraneti, Pengaruh frekuensi pemberian pakan pada kondisi gelap terhadap pertumbuhan dan sintasan benih ikan lele dumbo (Clarias gariepinus), Aquacoastmarine, 2 (2014) 1-6. [In Bahasa Indonesia]

[7] E.A. Khallaf, M. Galal, M.M.N. Authman, R.A.Zaid, A comparative study on the water quality of two nilotic canals in the delta of Egypt, Journal of aquaculture research \& development, 7 (2016) 462-467. DOI: 10.4172/2155-9546.1000462

[8] E. Lintang, Firdaus, I. Nurcahyani, Sistem monitoring kualitas air pada kolam ikan berbasis wireless sensor network menggunakan komunikasi zigbee. Prosiding SNATIF Ke-4, 2017, ISBN:978-602-118050-1. [In Bahasa Indonesia]

[9] Afriansyah, D. Irma, H. Iwan. Keragaan nitrogen dan $\mathrm{t}$-phosfat pada pemanfaatan limbah budidaya ikan lele (Clarias gariepinus) oleh ikan peres (Osteochilus kappeni) dengan sistem resirkulasi, Jurnal ilmiah mahasiswa kelautan dan perikanan, 1 (2016) 252-261. [In Bahasa Indonesia]

[10] J.M. Ebeling, M.B. Timmons, J.J. Bisogni, Engineering analysis of the stoichiometry of photoautotrophic, autotrophic and heterotrophic removal of ammonia-nitrogen in aquaculture sistems, Aquaculture, 257 (2006) 346-358.

DOI: https://doi.org/10.1016/j.aquaculture.2006.03. 019

[11] R. Nivelle, V. Gennotte, E.J.K. Kalala, N.B. Ngoc, M. Muller, C. Melard, C. Rougeot, Temperature preference of nile tilapia (Oreochromis niloticus) juveniles induces spontaneous sex reversal, PloS One, 14 (2)
(2019) 1-19. DOI:
https://doi.org/10.1371/journal pone.0212504.

[12] D. Ernawati, Pengaruh Pemberian bakteri heterotrof terhadap kualitas air pada budidaya ikan lele dumbo (Clarias sp) tanpa pergantian air, Skripsi, Fakultas Perikanan dan Kelautan Universitas Airlangga, 2014. [In Bahasa Indonesia]

[13] M. Ghufran, Kordi, Panduan lengkap memelihara ikan air tawar di kolam terpal, Lily Publisher, Yogyakarta, 2010. [In Bahasa Indonesia]

[14] R. Hartika, Mustahal, A. Noerkhaerin, Tilapia blood parameters with the addition of different dose of prebiotics in feed, Jurnal Perikanan dan Kelautan, 4 (2014) 259-267. DOI: http://dx.doi.org/10.33512/jpk.v4i4.174

[15] A.G.M. Osman, K.Y. AbouelFadl, A.E.B.M.A.E. Reheem, U.M.Mahmoud, W.Kloas, M.A. Moustafa, Blood biomarkers in nile tilapia Oreochromis niloticus and African catfish Clarias gariepinus to evaluate water quality of the river nile, Journal of fisheries sciences. 12 (1) (2018) 01-15.

[16] G.A.Wedemeyer, Physiology of fish in intensive aquaculture systems, Chapman and hall, New York, 1996.

[17] J.A. Amar, Pengaruh pemberian tepung cacing tanah (L. rubellus) terhadap kekebalan tubuh ikan lele dumbo (C. gariepinus), Fakultas Perikanan dan Ilmu Kelautan, Universitas Brawijaya, Malang, 2011, pp. 88. [In Bahasa Indonesia]

[18] B. Zafalon-Silva, Y.D. Zebral, A. Bianchini, C.E. Da Rosa, L.F. Marins, E.P. Colares, P.E. Martinez, V.L. Bobrowski, R.B. Robaldo, Erythrocyte nuclear abnormalities and leukocyte profile in the Antarctic fish Notothenia coriiceps after exposure to shortand long-term heat stress, Polar biology vol 40 (9) (2017) 1755-1760. DOI: https://doi.org/10.1007/s00300- 017-2099y.E.

[19] Afrianto, E. Liviawaty, Z. Jamaris, Penyakit Ikan, Penebar Swadaya, Jakarta, 2015. [In Bahasa Indonesia] 